\title{
Application of Intercultural Awareness in College English Teaching
}

\author{
Yan Chen \\ Feixian College \\ Linyi University \\ Feixian, Linyi, Shandong, China
}

\begin{abstract}
Intercultural communication is one of the important parts in college English teaching and students are required to acquire the cultural knowledge of other countries, especially the English-speaking countries while learning the language. This article describes how to cultivate the intercultural awareness in college English teaching from the relationship between language and culture, status quo of college English teaching, definition of intercultural awareness and significance of the cultivation as well as methods for cultivating the intercultural awareness.
\end{abstract} awareness; cultivation

\section{INTRODUCTION}

A language that a nation owns is an important part and carrier of it and each of the chapters, sentences and words contains cultural information of the nation. Language and culture are a body that cannot be divided, the language can not go without the culture, which follows the culture; the culture depends on the language, and the culture will be expressed through the language. Considering that the language and the culture are closely related and interdependent, we should grasp the culture relative to the language that we are learning. Especially during the college English teaching, teachers are required to actively develop students' cultural awareness in order to stimulate students' interests in English learning and have the students' overall quality improved, which will lay a solid foundation for the students' study and work in the future.

\section{Status Quo of College English Teaching}

The College English Curriculum Requirements (Trial) released in China points out that college English should take English language knowledge and application skills, learning strategies and intercultural communication as main points; and the English teaching requirements in colleges are divided into three levels, that is, general requirements, high requirements and higher requirements, all of the three requirements get involved in the language knowledge, application skills, learning strategies and intercultural communication. Seen from these, the English-related culture learning is an important part in the college English teaching, which can not be ignored. Looking through the college English classroom teaching, it is not difficult for us to find that though most teachers have recognized the new concepts for teaching, yet most in many colleges and universities are still going on the old way: teachers make lectures, to which students are listening. The class teaching is focused on examoriented teaching, where grades or exams are overstressed, and most of the class teaching is interpretation of words, texts, followed by class exercises. In recent years, with the expanded admission by colleges and universities, the students admitted differ in results, and those who are poor in English have undervalued the learning of English, showing lower enthusiasm to English learning, which cause a worst atmosphere for English learning, it can seen apparently in Class $\mathrm{C}$ during the level-based teaching, and the students are unable to complete basic knowledge within a given time, it will be much more difficult for them to grasp the cultural knowledge. On the other hand, for the teaching resources are insufficient in some colleges and universities, some advanced tools for learning the cultural knowledge are unable to be used in the class teaching, which also affects the learning of cultural knowledge to some degree.

\section{SIGNIFICANCE OF INTERCULTURAL AWARENESS Cultivation}

Going with the rapid development of the global economy, China's comprehensive national strength is increasing, during the college English teaching, the training of intercultural awareness will not only help to change the status quo of English teaching in the country, but also meet the needs of compound talents by the country and even the world. On the one hand, according to the College English Curriculum Teaching Requirements (Trial)" in the country, cultural communication should be part of the college English teaching, which can not only change the one-way teaching mode in language, improve teachers' knowledge structure, enrich the teaching contents in class but also activate the classroom atmosphere, improve students' enthusiasm in English learning, making teachers willing to teach and students interested to learn, so as to promote the foreign language teaching and better the teaching effect and quality. For example, within the dialogue given at Unit 3, Book I, Experiencing English, a dialogue is given like this: Zhang: $\mathrm{Hi}$, Conie. Glad to see you could make it. Come on in. Coonie: Wow. Looks like the party in full swill. When the two are talking about the party, teachers may show students the differences between the East and the West at the time of 
party, dating or invitation, the East are accustomed to do it ahead of time, yet the West just do it a little late. For more examples, when teaching Things I Learned From Dad given at Unit 7, Book II, Experiencing English, teachers may show students the story of Father's Day in the West. Thus, it can not only activate the classroom atmosphere but also make students access cultural knowledge of the West so as to lay a solid foundation for the communication in the future. On the other hand, it is known to all that language is a base for communication, and the communication cannot be achieved without the language. in order to get the verbal communication well done, it is a must for us to grasp the differences between cultures. The rapid development of the global economy will attract all countries to a global village, and the connections between countries are frequent increasingly, especially after China's entry to the WTO, China has established close relations with European countries in economy and trade. Facing such a global economic development trend, it is difficult to imagine how a person who has no social and cultural knowledge of English countries can use English correctly to communicate. Therefore, only the English culture education is done throughout the college English teaching, making students accumulate rich cultural knowledge and master basic abilities of English communication can the embarrassment situations caused by the differences in culture between the East and the West be avoided, so as to well promote the communication and reach the goals as expected. For example, those who know the cultural diversity between the East and the West will not ask questions such as "Are you married?" "How old are you? Do you have any boyfriends?" for these are taken as privacies in the West, and no one is will to reveal. Here is another dialogue between a Chinese girl and a foreign student: Tom: Hi, good morning, Zhang. You look so beautiful today. Zhang: Oh, where, where. In the dialogue, Tom will feel awkward on how to continue it, for modesty is one of the traditional virtues of Chinese, which is often used for self-effacing, when a Chinese is praised for look, clothes and the like, he or she will be always be modest, saying no, it is not and so on. However, when such praise is denied by Chinese, foreigners often doubt whether they do something wrong, such communications may fail finally. Therefore, during the teaching, teachers should teach students to say Thank you when they are praised by foreigners.

\section{METHODS FOR THE TRAINING OF INTERNATIONAL AWARENESS IN COLLEGE ENGLISH TEACHING}

Under the situation of economic globalization, teachers, facing more and more teaching methods and tools emerging today, are required to adapt to the needs of the new development as soon as possible, adjust the teaching thoughts, widen the teaching views, improve the cultural quality of their own and focus on students and take them as main bodies as well as combine the teaching methods with the students' cognitive structure and life experience so as to implement an effective intercultural education.

\section{A. Change Traditional Class Teaching Modes and Integrate Cultural Knowledge to the Class Teaching.}

Traditionally the teaching mode is based on unit teaching, stressing correct phonetics and tones, large in vocabulary, focusing on lexical collocation and usage, high in examoriented contents, but neglecting cultural factors. In class teaching, teachers are main bodies, what students do are listening in class and doing exercises after class. Generally the students trained this way will have solid foundation, able to master how to use words skillfully and use English to write. However, due to the lack of foreign culture, the students do not how to understand and use foreign language correctly and unable to communicate normally. Therefore, teachers are required to change the class teaching modes and introduce more cultural knowledge in class and train students' intercultural awareness. For example, when teaching the word Christmas, teachers may show students habits of the West when spending the festival, and may also list more words related to the Christmas such as Christmas card, reindeer, Christmas Eve, Santa Claus, roast turkey, sleigh bells and so on. As such, the students cannot only understand the cultural knowledge, but also grasp the Christmas - related words, the class efficiency is greatly improved.

\section{B. Strengthen Teachers' Cultural Accomplishment.}

During the college English teaching, teachers are still main bodies in teaching and disseminators of the language knowledge, since the teachers play an important role in the language teaching, in order to introduce cultural knowledge in teaching, the teachers have to have the cultural accomplishment of their own strengthened, understanding the differences between the East and the West in call, greeting, thanks, modesty, praise, care, talk and values; be familiar with the diversity between the East and the West in custom, values, thinking and religious beliefs and the like.

\section{Fully Make Use of Modern Teaching Tools.}

Modern teaching tools mainly include five devices namely episcope, projector, video-player, video tape recorder, radio cassette recorder; and one screen, namely CAT, computer network, campus high-speed network system. The use of modern educational tools will change the traditional teaching modes, which will lead to changes of teachers in educational thoughts, concepts and models and also the changes of students in learning thought, concepts and ways, it will stimulate students' interests and help them perceive, understand and get knowledge so as to internalize the quality of their own and play a solid knowledge base for the development in the future.

\section{CONCLUSION}

Language and culture are closely related, a language may reflect the rich and colorful cultural forms of the nation. Though we have realized that the cultural differences are existing and objective, yet any of a nation's culture is vast and all-inclusive, therefore, during the college English teaching, teachers should integrate the culture to the teaching in addition to necessary language knowledge, helping 
students cultivate interests in learning the language, making them capable of English listening, speaking, reading, writing, translation and becoming compound talents meeting the needs of the time.

\section{REFERENCES}

[1] Chen Caixia, Intercultural Awareness Cultivation in College English Teaching [J]. Journal of Bingtuan Education Institute, 2009 (2).

[2] Department of Higher Education, Ministry of Education. The College English Curriculum Requirements [M]. Beijing: Foreign Language and Teaching Press, 2007.

[3] Jiang Junli, Chen Jiang, Intercultural Awareness Cultivation in English Teaching $[\mathrm{J}]$. Journal of Hunan Radio and Television University, 2008 (3).

[4] Yang Ming'e, Importance of Intercultural Awareness Cultivation in English Teaching [J]. Guangxi Journal of Light Industry, 2009 (7).

[5] Zhao Li, Intercultural Awareness Cultivation and Penetration in English Teaching [J]. Heilongjiang Higher Education Research, 2007 (6). 